\title{
Editorial PIAM March 2021
}

\author{
Eujin Pei ${ }^{1}$
}

Accepted: 30 March 2021 / Published online: 9 April 2021

(c) The Author(s), under exclusive licence to Springer Nature Switzerland AG 2021

2020 has been an unprecedented year for many businesses. In light of these challenges, there are winners and losers. Companies such as Amazon, Netflix and Zoom have benefited from the lockdown, while the travel, tourism and hospitality sector have been more severely affected. The civil aerospace sector has been hit, and the domino effect or chain reaction on the manufacturing industry and its associated services have been felt. For example, Rolls-Royce's business very much depends on the return of air travel, since the company only earns money when planes fly or the number of hours its engines are in the air $[1,2]$. The company is paid on the number of hours that its engines are in use, in what we call a Product-Service-System (PSS) approach where products and services are seen as a combined, revenue-generating value proposition focused on selling function or availability rather than just the physical product alone. In such a "useoriented PSS" approach, the functionality of the engine is sold rather than the product through "Power by the hour" from Rolls Royce. Similarly, in a service-oriented PSS, the engine is sold together with a monitoring system that tracks and monitors its use [3].

Despite these benefits, few studies have tried to assess Additive Manufacturing (AM) through the lens of PSS, with the exception of Durugbo and Beltagui [4] and Zanetti et al. [5] who highlighted the potential servitisation of AM, despite the fact that maturity of AM still may be a barrier towards widespread adoption. The work by Zanardini et al. [6] also discussed the key drivers in promoting AM within a PSS business model, such as its ability to respond to market needs and being connected to the digital chain and supporting co-creation and customization. There is a need to report more of such case studies and ongoing research. The Progress in Additive Manufacturing Journal welcomes contributions about industry case studies, the economic impact of AM, as well as emerging business models. Do write to us and we'll be happy to hear from you. In the meantime, stay safe and have a good summer.

\section{References}

1. BBC News (2021a) Rolls-Royce says 'worst behind us' as it posts $£ 4$ bn loss. From: https://www.bbc.co.uk/news/business-56357312. Accessed on: 23 Mar 2021

2. BBC News (2021b) Rolls Royce plans summer shutdown to help cut losses. From: https://www.bbc.co.uk/news/business-55974 073. Accessed on: 23 Mar 2021

3. Johanna WN, Koteshwar C, Anthony T (2013) Developing PSS concepts from traditional product sales situation: the use of Business Model Canvas. In: Product lifetimes and the environment (PLATE) conference. https://doi.org/10.1007/978-3-642-308208_23.

4. Durugbo C, Beltagui A (2015) Industrial services for 3D manufacturers: an analysis. In: Operations management for sustainable competitiveness EurOMA conference, Neuchatel, 26 June-1 July

5. Zanetti V, Cavalieri S, Pezzotta G (2016) Additive manufacturing and PSS: a solution life-cycle perspective. IFAC-Papers OnLine 49(12):1573-1578

6. Zanardini $\mathrm{M}$ et al (2016) Additive Manufacturing applications in the domain of Product Service System: an empirical overview. Procedia CIRP 47:543-548

Publisher's Note Springer Nature remains neutral with regard to jurisdictional claims in published maps and institutional affiliations.
Eujin Pei

eujin.pei@brunel.ac.uk

1 Brunel University London, Uxbridge, UK 